ACTA AGROBOTANICA

Vol. 61 (2): 121-129

2008

\title{
FLOWERING DYNAMICS OF PEACH-LEAVED BELLFLOWER (CAMPANULA PERSICIFOLIA L.) 'ALBA' TREATED WITH BIOREGULATORS, GROWN IN AN UNHEATED PLASTIC TUNNEL AND IN FIELD
}

\author{
Elżbieta Pogroszewska, Patrycja Sadkowska
}

\author{
Institute of Ornamental Plants and Architecture of Landscape, University of Life Sciences in Lublin, Leszczyńskiego 58, \\ 20-068 Lublin, Poland \\ e-mail: epogroszewska@autograf.pl
}

Received: 3.10 .2007

$\mathrm{S} \mathrm{u} \mathrm{m} \mathrm{m} \mathrm{a} \mathrm{r} \mathrm{y}$

The effect of $\mathrm{BA}, \mathrm{GA}_{3}$ and $\mathrm{BA}+\mathrm{GA}_{3}$ on flowering of peach-leaved bellflower (Campanula persicifolia L.) 'Alba', grown in an unheated plastic tunnel or in open field, was investigated. Bioregulators at the following applications: 0, 100, 200, $400 \mathrm{mg} \mathrm{x} \mathrm{dm}^{-3}$, were applied foliarly twice. It has been found that the cultivation of peach-leaved bellflower in an unheated plastic tunnel accelerates flowering of plants by about $2-3$ weeks, compared to open field cultivation, in the first and second year of flowering of plants. It is advisable to apply gibberellic acid at a concentration of $400 \mathrm{mg} \mathrm{x} \mathrm{dm}^{-3}$ in plastic tunnel cultivation of bellflower and at a concentration of $200 \mathrm{mg} \mathrm{x} \mathrm{dm}^{-3}$ in field cultivation, since this treatment accelerates flowering by $2-9$ days. It is recommended that gibberellic acid should be applied at a concentration of $400 \mathrm{mg} \mathrm{x} \mathrm{dm}^{-3}$, which extends the flowering period of peach-leaved bellflower grown in a plastic tunnel by $6-13$ days. When peach-leaved bellflower is grown in an unheated plastic tunnel, full flowering is predicted to occur in the first or second week from the beginning of flowering of plants. When bellflower is grown in open field, full bloom of inflorescences is expected in the second week of flowering of plants. Irrespective of the type of substance applied in both years of cultivation, in the unheated plastic tunnel the largest amount of inflorescences was ready for cutting in the first decade of June, and in the field in the second decade of June.

Key words: Campanula persicifolia, benzyladenine, gibberellic acid, flowering

\section{INTRODUCTION}

One of the most ornamental species of perennial bellflowers is peach-leaved bellflower (Campanula persicifolia $\mathrm{L}$.). It is used not only in garden plantings, but also for cut flower cultivation. Bellflower produces large, light blue, less frequently white flowers. Both inflorescence stems, reaching $30-90 \mathrm{~cm}$, and single flowers are used by florists.
The flowering date of plants can be affected by applying plant bioregulators. Gibberellic acid (L e Nard and De Hertogh, 1993; Jankiewicz, 1997; Treder et al. 1999) or benzyladenine (K ostenyuk et al. 1999) may cause earlier flowering. However, benzyladenine sometimes delays flowering of plants (Saniewski and Kawa-Miszczak, 1992).

Flowering of ornamental plants can be accelerated, without large expenditures, by using an unheated plastic tunnel. In our climate, ornamental plants are grown in unheated plastic tunnels from March to October, and even the beginning of November ( $\mathrm{L}$ i s i e c k a et al. 1993). An unheated plastic tunnel is used for cultivation of many ornamental plant species in order to obtain earlier crops of inflorescence shoots (Hetman and Pogroszewska, 1996a; 1997; Szczepaniak, 2000a).

The aim of the present experiment was to investigate the effects of benzyladenine (BA) and gibberellic acid $\left(\mathrm{GA}_{3}\right)$, applied at different concentrations, on the flowering pattern of peach-leaved bellflower (Campanula persicifolia L.) grown in an unheated plastic tunnel and in field.

\section{MATERIALS AND METHODS}

The experiment was conducted in the years 2004 and 2005. The object of the study was peach-leaved bellflower plants (Campanula persicifolia L.) 'Alba' planted in October 2003 in native soil in an unheated plastic tunnel and in field, on $1.5 \mathrm{~m}$ wide patches in three rows. The investigations were carried out in the first and second year of flowering of plants.

Benzyladenine, gibberellic acid and benzyladenine + gibberellic acid were applied at the following concentrations: $0,100,200$ and $400 \mathrm{mg} \mathrm{x} \mathrm{dm}^{-3}$ (of each 
substance). Bioregulators were applied foliarly twice, and control plants were treated with distilled water. The plants, both those growing in the field and in the tunnel, were treated with the formulation (at an amount of $40 \mathrm{ml}$ of solution per plant) for the first time when they reached a height of $16-20 \mathrm{~cm}$. The second spraying took place when the plants reached a height of about $40 \mathrm{~cm}$ ( $60 \mathrm{ml}$ of solution was used per plant). The bellflower plants, both in the field and in the tunnel, were systematically fertilised and irrigated.

During the experiment, observations of the flowering dynamics of the plants were carried out.
The date of beginning of flowering (the first developing inflorescences in each combination), full flowering (the date on which the largest amount of inflorescence shoots reached commercial maturity) as well as the date of end of flowering (the last inflorescences cut) were recorded. The percentage share of flowering inflorescence shoots cut at three-day intervals in the total number of flowering inflorescences in a given combination was determined. Inflorescence shoots were cut after the opening of the first three flowers in an inflorescence.

Table 1

Meteorological data based on measurements of the Meteorological Station of the University of Life Sciences, Lublin-Felin, made during the growing period of peach-leaved bellflower (Campanula persicifolia L.) 'Alba' in the years of study 2004-2005.

\begin{tabular}{|c|c|c|c|c|c|c|c|c|c|}
\hline \multirow{3}{*}{ Months } & \multicolumn{5}{|c|}{ Temperature in field in ${ }^{\circ} \mathrm{C}$} & \multicolumn{4}{|c|}{ Temperature in unheated plastic tunnel in ${ }^{\circ} \mathrm{C} *$} \\
\hline & \multicolumn{3}{|c|}{ Decade means } & \multirow{2}{*}{ Monthly mean } & \multirow{2}{*}{$\begin{array}{l}\text { Long-term } \\
\text { mean } \\
1951-2000\end{array}$} & \multicolumn{3}{|c|}{ Decade means } & \multirow{2}{*}{ Monthly mean } \\
\hline & I & II & III & & & I & II & III & \\
\hline \multicolumn{10}{|c|}{2004} \\
\hline May & 13.6 & 10.8 & 11.4 & 11.9 & 13.1 & 17.8 & 14.3 & 16.8 & 16.3 \\
\hline June & 15.7 & 15.8 & 16.1 & 15.8 & 17.0 & 21.9 & 23.2 & 21.4 & 22.1 \\
\hline \multicolumn{10}{|c|}{2005} \\
\hline May & 10.8 & 10.5 & 18.0 & 13.1 & 13.1 & 15.0 & 14.9 & 21.2 & 17.0 \\
\hline June & 13.4 & 17.2 & 17.4 & 16.0 & 17.0 & 23.7 & 22.1 & 21.3 & 22.3 \\
\hline
\end{tabular}

* according to the authors' measurements

Thermal conditions in 2004, both in the open field and in the unheated plastic tunnel, were less favourable for the growth of peach-leaved bellflower than in 2005 (Tab. 1). In the field, in 2004 mean monthly temperatures in May and June were lower than longterm means. In 2005 mean monthly temperature in May did not differ from the long-term mean, and in June it was lower by $1^{\circ} \mathrm{C}$. The highest temperature was recorded in the $3 \mathrm{rd}$ decade of June in 2004, and in 2005 in the 3rd decade of May. In the plastic tunnel, mean monthly temperatures in May and June, that is, in the period of bellflower flowering, in both years of the experiment, were higher than in the field by about $4^{\circ} \mathrm{C}$ up to about $6^{\circ} \mathrm{C}$, respectively. In 2004 the highest temperature was recorded in the 2 nd decade of June, and in 2005 - in the 1st decade of June.

\section{RESULTS AND DISCUSSION}

The cultivation of peach-leaved bellflower (Campanula persicifolia L.) 'Alba' in the unheated plastic tunnel allowed obtaining flowering inflorescence shoots $2-3$ weeks earlier compared to field cul- tivation, in both years of flowering of the plants. The first inflorescence shoots of bellflower in the unheated plastic tunnel were cut on 19 May (1st year) and 25 May (2nd year). In the field, the first flowering inflorescence shoots were ready for cutting on 9 June (1st year) and 6 June (2nd year) (Tab. 2).

As reported by Van de Wiel (1989), the use of a plastic tunnel accelerates flowering of Campanula glomerata, C. medium, C. persicifolia, which is confirmed by the results of the present study. According to S zczepaniak (2000b), the cultivation of clustered bellflower (Campanula glomerata) and peach-leaved bellflower ( $C$. persicifolia) in a plastic tunnel accelerates flowering by 2 weeks. In an experiment on Chinese peony (Paeonia lactiflora Pall.), Hetman and Pogroszewska (1996b) found that flowers could be harvested $2-3$ weeks earlier than in field. Hetman and P o groszew s ka (1996a) and Pogroszewska (1998), when investigating the usefulness of an unheated plastic tunnel for the cultivation of certain perennial plants, found that the use of the plastic tunnel accelerated flowering of Lenten rose (Helleborus $x$ hybridus) by $12-23$ days 
and flowering of Siberian iris (Iris sibirica) by $1-3$ weeks compared to field cultivation. Dianthus barbatus plants under unheated plastic bloomed $4-8$ days earlier than those grown in field ( $\mathrm{J}$ a nowska and

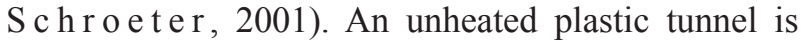
also used with success for the cultivation of Aquilegia $x$ hybrida, Anemone coronaria, Dicentra spectabilis, Doronicum caucasicum, Primula elatior, Tanacetum coccineum, Trollins $x$ hybridus (B a c h, 1989).

In the present experiment, the application of gibberellic acid accelerated flowering of the peach- leaved bellflower plants. In the first year of flowering, the bellflower plants treated with gibberellic acid at a concentration of $\mathrm{GA}_{3}-400 \mathrm{mg} \mathrm{x} \mathrm{dm}{ }^{-3}$ were the first to bloom in the unheated plastic tunnel (19 May), whereas in the field those also treated with gibberellic acid, but at a concentration of $\mathrm{GA}_{3}-200 \mathrm{mg} \mathrm{x} \mathrm{dm}^{-3}$ (9 June). The application of gibberellic acid at these concentrations accelerated flowering of the plants by 9 days in the tunnel and by 2 days in the field compared to the control plants (Tab. 2).

Table 2

Characteristics of flowering of peach-leaved bellflower (Campanula persicifolia L.) 'Alba' grown in an unheated plastic tunnel and in field, subjected to the effect of bioregulators.

\begin{tabular}{|c|c|c|c|c|c|c|c|c|c|}
\hline \multirow{2}{*}{$\begin{array}{l}\text { Culti- } \\
\text { vation } \\
\text { place }\end{array}$} & \multirow{2}{*}{$\begin{array}{l}\text { Bioregulator } \\
\left(\mathrm{mg} \mathrm{x} \mathrm{dm}^{-3}\right)\end{array}$} & \multicolumn{2}{|c|}{ Start of flowering } & \multicolumn{2}{|c|}{ Full flowering } & \multicolumn{2}{|c|}{ End of flowering } & \multicolumn{2}{|c|}{$\begin{array}{l}\text { Length of flowering } \\
\text { period (days) }\end{array}$} \\
\hline & & $\begin{array}{l}1 \text { st year of } \\
\text { flowering }\end{array}$ & $\begin{array}{c}\text { 2nd year of } \\
\text { flowering }\end{array}$ & $\begin{array}{l}1 \text { st year of } \\
\text { flowering }\end{array}$ & $\begin{array}{l}\text { 2nd year of } \\
\text { flowering }\end{array}$ & $\begin{array}{l}1 \text { st year of } \\
\text { flowering }\end{array}$ & $\begin{array}{l}\text { 2nd year of } \\
\text { flowering }\end{array}$ & $\begin{array}{l}1 \text { st year of } \\
\text { flowering }\end{array}$ & $\begin{array}{l}\text { 2nd year of } \\
\text { flowering }\end{array}$ \\
\hline \multirow{10}{*}{ 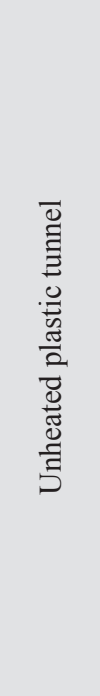 } & 0 & 28.05 & 28.05 & 7.06 & 4.06 & 14.06 & 10.06 & 17 & 13 \\
\hline & $\mathrm{GA}_{3} 100$ & 26.05 & 28.05 & 7.06 & 1.06 & 16.06 & 10.06 & 17 & 13 \\
\hline & $\mathrm{GA}_{3} 200$ & 25.05 & 26.05 & 3.06 & 4.06 & 15.06 & 14.06 & 21 & 19 \\
\hline & $\mathrm{GA}_{3} 400$ & 19.05 & 25.05 & 7.06 & 2.06 & 18.06 & 13.06 & 30 & 19 \\
\hline & BA 100 & 28.05 & 29.05 & 4.06 & 6.06 & 17.06 & 10.06 & 20 & 14 \\
\hline & BA 200 & 28.05 & 29.05 & 4.06 & 3.06 & 16.06 & 12.06 & 19 & 16 \\
\hline & BA 400 & 28.05 & 29.05 & 9.06 & 3.06 & 14.06 & 14.06 & 17 & 18 \\
\hline & $\mathrm{BA}+\mathrm{GA}_{3} 100$ & 28.05 & 29.05 & 8.06 & 3.06 & 15.06 & 13.06 & 18 & 17 \\
\hline & $\mathrm{BA}+\mathrm{GA}_{3} 200$ & 31.05 & 29.05 & 8.06 & 4.06 & 13.06 & 10.06 & 13 & 14 \\
\hline & $\mathrm{BA}+\mathrm{GA}_{3} 400$ & 28.05 & 28.05 & 7.06 & 3.06 & 15.06 & 12.06 & 18 & 17 \\
\hline \multirow{10}{*}{$\frac{0}{2}$} & 0 & 11.06 & 10.06 & 18.06 & 17.06 & 22.06 & 20.06 & 11 & 10 \\
\hline & $\mathrm{GA}_{3} 100$ & 11.06 & 11.06 & 18.06 & 19.06 & 23.06 & 26.06 & 12 & 15 \\
\hline & $\mathrm{GA}_{3} 200$ & 9.06 & 6.06 & 18.06 & 17.06 & 25.06 & 22.06 & 16 & 16 \\
\hline & $\mathrm{GA}_{3} 400$ & 10.06 & 10.06 & 17.06 & 17.06 & 25.06 & 22.06 & 15 & 12 \\
\hline & BA 100 & 11.06 & 10.06 & 18.06 & 18.06 & 25.06 & 23.06 & 14 & 13 \\
\hline & BA 200 & 11.06 & 10.06 & 18.06 & 19.06 & 22.06 & 28.06 & 11 & 18 \\
\hline & BA 400 & 11.06 & 10.06 & 18.06 & 19.06 & 24.06 & 24.06 & 12 & 14 \\
\hline & $\mathrm{BA}+\mathrm{GA}_{3} 100$ & 12.06 & 11.06 & 17.06 & 18.06 & 25.06 & 22.06 & 13 & 11 \\
\hline & $\mathrm{BA}+\mathrm{GA}_{3} 200$ & 13.06 & 11.06 & 17.06 & 18.06 & 26.06 & 21.06 & 13 & 10 \\
\hline & $\mathrm{BA}+\mathrm{GA}_{3} 400$ & 12.06 & 10.06 & 18.06 & 18.06 & 24.06 & 21.06 & 12 & 11 \\
\hline
\end{tabular}


The obtained results are similar to the results of a study of Treder et al. (1999) on the acceleration of flowering of cyclamen using gibberellic acid. Similar results were obtained by L e $\mathrm{N}$ ard and De Hertog h (1993) in their study on tulip. However, data obtained in the present study are not consistent with the results of an experiment conducted by $\mathrm{F}$ a r o o qi et al. (1994) in which the application of gibberellic acid delayed flowering of roses.

In the first year of the present experiment, the date of full flowering of the bellflower plants grown in the plastic tunnel and treated with $\mathrm{GA}_{3}$ was dependent on the concentration of the bioregulator (Tab. 2). In the control plants and those sprayed with $\mathrm{GA}_{3}-100$ $\mathrm{mg} \mathrm{x} \mathrm{dm}{ }^{-3}$, the largest amount of inflorescences was ready for cutting, respectively: in the middle and at the end of the 2nd week of flowering of the plants in these combinations, in the plants treated with $\mathrm{GA}_{3}-200 \mathrm{mg}$ $\mathrm{x} \mathrm{dm} \mathrm{m}^{-3}$ - in the middle of the 2 nd week of flowering of the plants treated with gibberellic acid at this concentration, and in the case of $\mathrm{GA}_{3}-400 \mathrm{mg} \mathrm{x} \mathrm{dm}^{-3}$ - at the end of the 3rd week of flowering of the plants in this combination (Tab. 3). In the field, full bloom of inflo- rescences of the plants influenced by $\mathrm{GA}_{3}$ at all concentrations, as well as of the control plants, occurred in the 2 nd week of their flowering.

Benzyladenine did not cause earlier flowering of the plants. In the 1st year of the study, the plants treated with benzyladenine started flowering on the same date as the control plants: 28 May (tunnel) and 11 June (field) (Tab. 2). A study of S a n i e w s k i and K aw a-M is zczak (1992) proves that benzyladenine sometimes even delays flowering of plants.

In the 1 st year of the study, the plants growing in the plastic tunnel and treated with BA - $100 \mathrm{mg} x$ $\mathrm{dm}^{-3}$ and BA $-200 \mathrm{mg} \mathrm{x} \mathrm{dm}{ }^{-3}$ flowered quite evenly. Full flowering of the plants subjected to the effect of $\mathrm{BA}-400 \mathrm{mg} \mathrm{x} \mathrm{dm}{ }^{-3}$ was noted in the 2 nd week of flowering of the tunnel-grown plants treated with this formulation, similarly to the control plants (Tab. 4). In the field, the plants treated with BA at all concentrations, analogously to the control plants, produced the largest amount of inflorescences mature for harvesting in the 2nd week of flowering of the plants in each combination.

Table 3

The effect of $\mathrm{GA}_{3}$ on the flowering dynamics of peach-leaved bellflower (Campanula persicifolia $\mathrm{L}$.)

'Alba' grown in an unheated plastic tunnel and in field in the 1st year of flowering.

\begin{tabular}{|c|c|c|c|c|c|c|c|c|}
\hline \multirow{3}{*}{ Date of observation } & \multicolumn{8}{|c|}{ Number of developed inflorescences (\%) } \\
\hline & \multicolumn{2}{|c|}{ Control } & \multicolumn{2}{|c|}{$\mathrm{GA}_{3} 100 \mathrm{mgxdm}^{-3}$} & \multicolumn{2}{|c|}{ GA3 $200 \mathrm{mgxdm}^{-3}$} & \multicolumn{2}{|c|}{ GA3 $400 \mathrm{mgxdm}^{-3}$} \\
\hline & tunnel & field & tunnel & field & tunnel & field & tunnel & field \\
\hline $19.05-21.05$ & & & & & & & 1.7 & \\
\hline $22.05-24.05$ & & & & & & & 2.4 & \\
\hline $25.05-27.05$ & & & 1.0 & & 1.5 & & 3.3 & \\
\hline 28.05-30.05 & 5.4 & & 1.5 & & 13.4 & & 2.2 & \\
\hline $31.05-02.06$ & 11.0 & & 5.3 & & 9.5 & & 3.0 & \\
\hline 03.06-05.06 & 14.3 & & 10.6 & & 25.9 & & 12.6 & \\
\hline 06.06-08.06 & 37.8 & & 50.3 & & 20.4 & & 29.6 & \\
\hline 09.06-11.06 & 26.2 & 3.0 & 17.6 & 4.4 & 17.0 & 13.5 & 23.0 & 4.0 \\
\hline 12.06-14.06 & 5.3 & 19.8 & 11.3 & 24.2 & 10.9 & 20.2 & 16.6 & 11.4 \\
\hline $15.06-17.06$ & & 33.0 & 2.4 & 23.4 & 1.4 & 21.1 & 5.2 & 39.5 \\
\hline $18.06-20.06$ & & 38.2 & & 42.5 & & 31.1 & 0.4 & 26.1 \\
\hline $21.06-23.06$ & & 6.0 & & 5.5 & & 12.5 & & 14.2 \\
\hline $24.06-26.06$ & & & & & & 1.6 & & 4.8 \\
\hline
\end{tabular}


Table 4

The effect of BA on the flowering dynamics of peach-leaved bellflower (Campanula persicifolia L.)

'Alba' grown in an unheated plastic tunnel and in field in the 1st year of flowering.

\begin{tabular}{|c|c|c|c|c|c|c|c|c|}
\hline \multirow{3}{*}{ Date of observation } & \multicolumn{8}{|c|}{ Number of developed inflorescences (\%) } \\
\hline & \multicolumn{2}{|c|}{ Control } & \multicolumn{2}{|c|}{ BA $100 \mathrm{mgxdm}^{-3}$} & \multicolumn{2}{|c|}{ BA $200 \mathrm{mgxdm}^{-3}$} & \multicolumn{2}{|c|}{ BA $400 \mathrm{mgxdm}^{-3}$} \\
\hline & tunnel & field & tunnel & field & tunnel & field & tunnel & field \\
\hline $28.05-30.05$ & 5.4 & & 3.3 & & 5.7 & & 4.8 & \\
\hline $31.05-02.06$ & 11.0 & & 17.9 & & 17.9 & & 8.3 & \\
\hline 03.06-05.06 & 14.3 & & 25.3 & & 22.9 & & 14.5 & \\
\hline 06.06-08.06 & 37.8 & & 24.9 & & 20.4 & & 20.7 & \\
\hline 09.06-11.06 & 26.2 & 3.0 & 18.9 & 2.3 & 22.9 & 1.1 & 40.4 & 2.2 \\
\hline $12.06-14.06$ & 5.3 & 19.8 & 6.9 & 22.6 & 8.7 & 21.0 & 11.3 & 17.5 \\
\hline $15.06-17.06$ & & 33.0 & 2.8 & 15.8 & 1.5 & 25.2 & & 25.5 \\
\hline $18.06-20.06$ & & 38.2 & & 44.7 & & 45.4 & & 44.3 \\
\hline $21.06-23.06$ & & 6.0 & & 12.1 & & 7.3 & & 9.2 \\
\hline $24.06-26.06$ & & & & 2.5 & & & & 1.3 \\
\hline
\end{tabular}

Table 5

The effect of $\mathrm{BA}+\mathrm{GA}_{3}$ on the flowering dynamics of peach-leaved bellflower (Campanula persicifolia $\mathrm{L}$.)

'Alba' grown in an unheated plastic tunnel and in field in the 1st year of flowering.

\begin{tabular}{|c|c|c|c|c|c|c|c|c|}
\hline \multirow{3}{*}{ Date of observation } & \multicolumn{8}{|c|}{ Number of developed inflorescences (\%) } \\
\hline & \multicolumn{2}{|c|}{ Control } & \multicolumn{2}{|c|}{$\mathrm{BA}+\mathrm{GA}_{3} 100 \mathrm{mgxdm}^{-3}$} & \multicolumn{2}{|c|}{$\mathrm{BA}+\mathrm{GA}_{3} 200 \mathrm{mgxdm}^{-3}$} & \multicolumn{2}{|c|}{$\mathrm{BA}+\mathrm{GA}_{3} 400 \mathrm{mgxdm}^{-3}$} \\
\hline & tunnel & field & tunnel & field & tunnel & field & tunnel & field \\
\hline $28.05-30.05$ & 5.4 & & 3.4 & & & & 3.6 & \\
\hline $31.05-02.06$ & 11.0 & & 10.0 & & 5.6 & & 5.7 & \\
\hline 03.06-05.06 & 14.3 & & 24.2 & & 10.9 & & 6.6 & \\
\hline 06.06-08.06 & 37.8 & & 33.7 & & 46.6 & & 32.9 & \\
\hline 09.06-11.06 & 26.2 & 3.0 & 20.8 & & 33.0 & & 31.9 & \\
\hline $12.06-14.06$ & 5.3 & 19.8 & 7.5 & 29.4 & 3.9 & 16.6 & 17.7 & 16.4 \\
\hline $15.06-17.06$ & & 33.0 & 0.4 & 35.6 & & 37.7 & 1.6 & 26.4 \\
\hline $18.06-20.06$ & & 38.2 & & 26.5 & & 33.9 & & 45.9 \\
\hline $21.06-23.06$ & & 6.0 & & 7.5 & & 9.8 & & 10.8 \\
\hline $24.06-26.06$ & & & & 1.0 & & 2.0 & & 0.5 \\
\hline
\end{tabular}

The application of benzyladenine in combination with gibberellic acid, in the 1st year of flowering of the plants, similarly to benzyladenine alone, did not accelerate flowering of bellflower, and in the case of $\mathrm{BA}+\mathrm{GA}_{3}-200 \mathrm{mg} \mathrm{x} \mathrm{dm}{ }^{-3}$, it even delayed flowering by 3 days (tunnel) and by 2 days (field) (Tab. 2).
In the 1st year of flowering of the plants, in the plastic tunnel-grown plants sprayed with $\mathrm{BA}+\mathrm{GA}_{3}$ at all concentrations, similarly to the control plants, the largest amount of inflorescences was ready for cutting in the 2 nd week of flowering of the plants in these combinations. In the field, full bloom of inflorescences 
in those plants in which $\mathrm{BA}+\mathrm{GA}_{3}$ was applied at all concentrations was noted in the 1st week of their flowering (Tab. 5).

The applied bioregulators differentiated the length of bellflower flowering period. In the first year of the present experiment, the plants growing in the unheated plastic tunnel and treated with $\mathrm{GA}_{3}-400 \mathrm{mg}$ $\mathrm{x} \mathrm{dm}{ }^{-3}$ were characterised by the longest flowering period (30 days). In the field, the longest flowering duration was noted in the plants sprayed with $\mathrm{GA}_{3}-200 \mathrm{mg}$ $\mathrm{x} \mathrm{dm}{ }^{-3}$ (16 days). The control plants flowered shorter: in the plastic tunnel 17 days, in the field 11 days.

In the second year of flowering, as in the first year, gibberellic acid at the same concentrations accelerated flowering of the studied species' plants. In the plastic tunnel, the application of $\mathrm{GA}_{3}-400 \mathrm{mg} \mathrm{x} \mathrm{dm}^{-3}$ accelerated flowering by 3 days ( 25 May), and in the field, the application of $\mathrm{GA}_{3}-200 \mathrm{mg} \mathrm{x} \mathrm{dm}^{-3}$ - by 4 days (6 June) compared to the control plants (Tab. 2).

In the second year, flowering of the plants which were treated with $\mathrm{GA}_{3}$ was more even compared to the first year. Full flowering of the plants treated with this bioregulator at all concentrations, in the plastic tunnel, fell on the end of the first week or the beginning of the second week of flowering of the plants in each combination. In the control, the largest amount of inflorescences was ready for cutting at the beginning of the second week of flowering of the plants in this combination. In the field, full bloom of inflorescences of the plants treated with $\mathrm{GA}_{3}-0,100,200$ and $400 \mathrm{mg}$ $\mathrm{x} \mathrm{dm}{ }^{-3}$, similarly to the control plants, occurred in the 2nd week of their flowering (Tab. 6).

In the unheated plastic tunnel, the plants in which benzyladenine was applied, flowered in the second year even 1 day later (29 May) than the control plants (28 May). In the field, they flowered on the same day as the plants in the control treatment (10 June) (Tab. 2).

In the second year of the study, the largest amount of inflorescences mature for cutting in the bellflower plants grown in the tunnel and treated with BA - 100 $\mathrm{mg} \mathrm{x} \mathrm{dm}{ }^{-3}$, as in the control treatment, was noted in the 2nd week of flowering of the plants in these combinations, and in the plants influenced by BA- 200 and 400 $\mathrm{mg} \mathrm{x} \mathrm{dm}{ }^{-3}$ - at the end of the first week of their flowering. In the field, full flowering of the plants sprayed with benzyladenine at all concentrations, likewise in the control plants, occurred in the second week of their flowering (Tab. 7).

In the second year of the experiment, both in the tunnel and in the field, the plants treated with $\mathrm{BA}+\mathrm{GA}_{3}$ at all concentrations did not accelerate flowering of the plants, similarly to the first year of the study (Tab. 2).

In the second year of the present experiment, in the unheated tunnel, full flowering of the plants treated

Table 6

The effect of $\mathrm{GA}_{3}$ on the flowering dynamics of peach-leaved bellflower (Campanula persicifolia $\mathrm{L}$.)

'Alba' grown in an unheated plastic tunnel and in field in the 2nd year of flowering.

\begin{tabular}{|c|c|c|c|c|c|c|c|c|}
\hline \multirow{3}{*}{ Date of observation } & \multicolumn{8}{|c|}{ Number of developed inflorescences (\%) } \\
\hline & \multicolumn{2}{|c|}{ Control } & \multicolumn{2}{|c|}{$\mathrm{GA}_{3} 100 \mathrm{mgxdm}^{-3}$} & \multicolumn{2}{|c|}{$\mathrm{GA}_{3} 200 \mathrm{mgxdm}^{-3}$} & \multicolumn{2}{|c|}{$\mathrm{GA}_{3} 400 \mathrm{mgxdm}^{-3}$} \\
\hline & tunnel & field & tunnel & field & tunnel & field & tunnel & field \\
\hline $25.05-27.05$ & & & & & 0.4 & & 3.2 & \\
\hline 28.05-30.05 & 2.4 & & 5.2 & & 3.0 & & 5.2 & \\
\hline $31.05-02.06$ & 29.6 & & 36.9 & & 28.9 & & 43.1 & \\
\hline 03.06-05.06 & 42.2 & & 33.1 & & 38.5 & & 40.4 & \\
\hline 06.06-08.06 & 21.6 & & 22.3 & & 17.4 & 0.7 & 10.5 & \\
\hline 09.06-11.06 & 4.2 & 4.0 & 1.4 & 0.1 & 6.5 & 1.1 & 1.9 & 0.6 \\
\hline $12.06-14.06$ & & 10.8 & & 8.7 & 5.1 & 5.7 & 0.5 & 7.3 \\
\hline 15.06-17.06 & & 48.7 & & 31.7 & & 46.4 & & 43.3 \\
\hline $18.06-20.06$ & & 36.5 & & 39.7 & & 40.8 & & 34.2 \\
\hline $21.06-23.06$ & & & & 11.7 & & 5.4 & & 18.2 \\
\hline $24.06-26.06$ & & & & 8.4 & & & & \\
\hline
\end{tabular}


Table 7

The effect of BA on the flowering dynamics of peach-leaved bellflower (Campanula persicifolia L.)

'Alba' grown in an unheated plastic tunnel and in field in the 2nd year of flowering.

\begin{tabular}{|c|c|c|c|c|c|c|c|c|}
\hline \multirow{3}{*}{ Date of observation } & \multicolumn{8}{|c|}{ Number of developed inflorescences (\%) } \\
\hline & \multicolumn{2}{|c|}{ Control } & \multicolumn{2}{|c|}{ BA $100 \mathrm{mgxdm}^{-3}$} & \multicolumn{2}{|c|}{ BA $200 \mathrm{mgxdm}^{-3}$} & \multicolumn{2}{|c|}{ BA $400 \mathrm{mgxdm}^{-3}$} \\
\hline & tunnel & field & tunnel & field & tunnel & field & tunnel & field \\
\hline $28.05-30.05$ & 2.4 & & 5.3 & & 2.3 & & 1.7 & \\
\hline $31.05-02.06$ & 29.6 & & 19.2 & & 31.4 & & 34.3 & \\
\hline 03.06-05.06 & 42.2 & & 32.4 & & 38.9 & & 38.4 & \\
\hline 06.06-08.06 & 21.6 & & 36.0 & & 14.6 & & 15.6 & \\
\hline 09.06-11.06 & 4.2 & 4.0 & 7.1 & 5.6 & 9.7 & 1.7 & 7.3 & 0.3 \\
\hline $12.06-14.06$ & & 10.8 & & 14.3 & 3.1 & 8.8 & 2.7 & 3.5 \\
\hline $15.06-17.06$ & & 48.7 & & 26.7 & & 12.5 & & 18.4 \\
\hline $18.06-20.06$ & & 36.5 & & 39.8 & & 48.0 & & 55.1 \\
\hline $21.06-23.06$ & & & & 13.6 & & 17.6 & & 21.7 \\
\hline $24.06-26.06$ & & & & & & 10.4 & & 1.0 \\
\hline $27.06-29.06$ & & & & & & 1.0 & & \\
\hline
\end{tabular}

Table 8

The effect of $\mathrm{BA}+\mathrm{GA}_{3}$ on the flowering dynamics of peach-leaved bellflower (Campanula persicifolia $\mathrm{L}$.)

'Alba' grown in an unheated plastic tunnel and in field in the 2nd year of flowering.

\begin{tabular}{|c|c|c|c|c|c|c|c|c|}
\hline \multirow{3}{*}{ Date of observation } & \multicolumn{8}{|c|}{ Number of developed inflorescences (\%) } \\
\hline & \multicolumn{2}{|c|}{ Control } & \multicolumn{2}{|c|}{$\mathrm{BA}+\mathrm{GA}_{3} 100 \mathrm{mgxdm}^{-3}$} & \multicolumn{2}{|c|}{$\mathrm{BA}+\mathrm{GA}_{3} 200 \mathrm{mgxdm}^{-3}$} & \multicolumn{2}{|c|}{$\mathrm{BA}+\mathrm{GA}_{3} 400 \mathrm{mgxdm}^{-3}$} \\
\hline & tunnel & field & tunnel & field & tunnel & field & tunnel & field \\
\hline $28.05-30.05$ & 2.4 & & 0.8 & & 0.3 & & 1.5 & \\
\hline 31.05-02.06 & 29.6 & & 20.7 & & 4.8 & & 14.5 & \\
\hline 03.06-05.06 & 42.2 & & 63.4 & & 50.9 & & 43.4 & \\
\hline 06.06-08.06 & 21.6 & & 9.6 & & 36.3 & & 23.3 & \\
\hline 09.06-11.06 & 4.2 & 4.0 & 3.9 & 2.0 & 7.7 & 0.3 & 16.5 & 0.1 \\
\hline $12.06-14.06$ & & 10.8 & 1.6 & 3.1 & & 2.8 & 0.8 & 0.9 \\
\hline $15.06-17.06$ & & 48.7 & & 21.4 & & 16.1 & & 20.9 \\
\hline $18.06-20.06$ & & 36.5 & & 57.2 & & 66.9 & & 76.1 \\
\hline $21.06-23.06$ & & & & 16.3 & & 13.9 & & 2.0 \\
\hline
\end{tabular}


with $\mathrm{BA}+\mathrm{GA}_{3}$ at all concentrations took place at the end of the first week of their flowering. In the control plants, which flowered most abundantly on a similar date, it was the beginning of the second week of their flowering. In the field, inflorescences of the plants subjected to the effect of $\mathrm{BA}+\mathrm{GA}_{3}$ at all concentrations, as in the control plants, matured for cutting in the largest number in the second week of their flowering (Tab. 8).

It should be stressed that, in both years of peachleaved bellflower cultivation in the plastic tunnel, the largest amount of inflorescences was cut in the 1st decade of June. In 2004 it was the second or third week from the beginning of flowering of the plants in each combination, and in 2005 (which was slightly warmer) - the first week in most cases. The date of full flowering was associated with high temperature prevailing in the tunnel at that time and it suggests the studied species' sensitivity to thermal conditions. In the field, the largest amount of inflorescences reached commercial maturity in the second decade of June and in both years of the study, it was in most cases the second week of flowering of the plants in each combination.

In the second year of the study, the flowering period of the plants depended both on the place of cultivation and the formulation applied. In the unheated plastic tunnel, the plants treated with $\mathrm{GA}_{3}-200 \mathrm{mg} \mathrm{x}$ $\mathrm{dm}^{-3}$ and $400 \mathrm{mg} \mathrm{x} \mathrm{dm}^{-3}$ flowered the longest (19 days) -6 days longer than the untreated plants. In the open field, the plants subjected to the effect of BA -200 $\mathrm{mg} \mathrm{x} \mathrm{dm}{ }^{-3}$ were characterised by the longest flowering period (18 days) -8 days longer than the flowering period of the control plants (Tab. 2).

\section{CONCLUSIONS}

1. The cultivation of peach-leaved bellflower (Campanula persicifolia L.) 'Alba' in an unheated plastic tunnel accelerates flowering of plants by about $2-3$ weeks, compared to open field cultivation, in the first and second year of flowering of plants.

2. It is advisable to apply gibberellic acid at a concentration of $400 \mathrm{mg} \mathrm{x} \mathrm{dm}^{-3}$ in bellflower cultivation in a plastic tunnel and at a concentration of $200 \mathrm{mg} \mathrm{x}$ $\mathrm{dm}^{-3}$ in field cultivation, since this treatment accelerates flowering by $2-9$ days.

3. It is recommended that gibberellic acid should be applied at a concentration of $400 \mathrm{mg} \mathrm{x} \mathrm{dm}^{-3}$, which extends the flowering period of peach-leaved bellflower grown in a plastic tunnel by $6-13$ days.

4. When peach-leaved bellflower is grown in an unheated plastic tunnel, full flowering is predicted to occur in the first or second week from the beginning of flowering of plants. When bellflower is grown in open field, full bloom of inflorescences is expected in the 2 nd week of flowering of plants.
5. Irrespective of the type of substance applied in both years of cultivation, in the unheated plastic tunnel, the largest amount of inflorescences was ready for cutting in the first decade of June, and in the field - in the second decade of June.

\section{REFERENCES}

Bach A., 1989. Kwiaty mogą zakwitnąć zimą. PWRiL, Warszawa.

Farooqi A. H. A., Shukla Y. N., Bansal R., Sharma S., 1994. Relationship between gibberellin and cytokinin activity and flowering in Rosa damascena Mill. Plant Growth Regul. 14 (2): 109-113.

Hetman J., Pogroszewska E., 1996a. Przyspieszona uprawa ciemiernika ogrodowego (Helleborus $x$ hybridus hort.) w nieogrzewanym tunelu foliowym i w polu. / Accelerated cultivation of Helleborus $x$ hybridus hort. in an unheated plastic tunnel and in the field. Materiały XI Ogólnopolskiego Zjazdu Kwiaciarzy, Skierniewice 16-17 May 1996: 43.

Hetman J., Pogroszewska E., 1996b. Porównanie kwitnienia polskich odmian piwonii chińskiej (Paeonia lactiflora) w nieogrzewanym tunelu foliowym i w polu. / Comparison of flowering of Polish cultivars of Chinese peony (Paeonia lactiflora) in an unheated plastic tunnel and in field. Zesz. Nauk. ATR Bydg. Ser. Rol. 197 (39): 87-98.

Hetman J., Pogroszewska E., 1997. Kwitnienie liatry kłosowej (Liatris spicata) uprawianej w nieogrzewanym tunelu foliowym i w polu, z zastosowaniem ściółkowania. / Flowering of Liatris spicata cultivated in an unheated plastic tunnel and in field with mulching application. Zesz. Probl. Post. Nauk Rol. 449: 61-74.

Jankiewicz L., 1997. Regulatory wzrostu i rozwoju roślin cz. 1 i 2 . / Plant growth and development regulators. Part 1 and 2. Wydawn. Nauk. PWN, Warszawa.

Janowska B., Schroeter A., 2001. Plonowanie goździka brodatego (Dianthus barbatus L.) uprawianego w gruncie odkrytym i w nieogrzewanym tunelu foliowym. / The yielding of Dianthus barbatus L. grown in the field and in an unheated plastic tunnel. Zesz. Nauk. AR w Krakowie, 379: 99-103.

Kostenyuk I., Oh B. J., So I. S., 1999. Induction of early flowering in Cymbidium niveomarginatum Mak in vitro. Plant Cell Reports, 19: 1-5.

Le Nard M., De Hertogh A. A., 1993. Tulipa. In: „The physiology of flower bulbs“. A. De Hertogh., M. Le Nard. (Eds.) Amsterdam-London-New York-Tokyo: 617-682.

Lisiecka A., Szczepaniak S., Krause J., 1993. Uprawa roślin ozdobnych $\mathrm{w}$ nieogrzewanych tunelach foliowych. / Ornamental plants cultivation in unheated plastic tunnels. Mat. z Konferencji „Oszczędne technologie w ogrodnictwie szklarniowym" SITO - NOT. Poznań, 23 - 24 February 1993: 72-77.

Pogroszewska E., 1998. Przyspieszona uprawa kosaćca syberyjskiego (Iris sibirica L.) w nieogrzewanym tunelu 
foliowym. / Accelerated cultivation of Siberian iris (Iris sibirica L.) in an unheated plastic tunnel. Fol. Univ. Agric. Stetin. Agricultura, 187 (70): 95-105.

Saniewski M., Kawa-Miszczak L., 1992. Hormonal control of growth and development of tulips. Acta Hort. 325: 43-54.

Szczepaniak S., 2000a. Plonowanie przymiotna ogrodowego (Erigeron hybridus Bergm.) i ostróżki ogrodowej (Delphinium $x$ cultorum Voss) w tunelu foliowym. / The height and quality of yield of Erigeron hybridus Bergm. and Delphinium x cultorum Voss in an unheated plastic tunnel. Roczn. Akad. Roln. Poznań. CCCXXIII, Ogrodn. 31, cz. 1: 171-175.

Szczepaniak S., 2000b. Uprawa wieloletnich dzwonków na kwiaty cięte. / The cultivation of perennial Campanula for cut flowers. Hasło Ogrodnicze, 9: 86-88.

Treder J., Matysiak B., Nowak J., 1999. The effect of gibberellic acid on growth and flowering of Cyclamen persicum Mill. Folia Hortic. 11 (2): 81-86.

Van de Wiel A., 1990. Teelt Campanula in tunnel. Keuze uitgangsmateriaal van groot belang. Vakblad voor de Bloemisterij, 45: 14: 52-53.

\author{
Dynamika kwitnienia \\ dzwonka brzoskwiniolistnego \\ (Campanula persicifolia L.) \\ 'Alba' traktowanego bioregulatorami, \\ uprawianego w nieogrzewanym tunelu foliowym \\ i w polu \\ Streszczenie
}

Zbadano wpływ BA, GA $\mathrm{GA}_{3} \mathrm{BA}+\mathrm{GA}_{3}$ na kwitnienie dzwonka brzoskwiniolistnego (Campanula persicifolia L.) 'Alba' uprawianego w nieogrzewanym tunelu foliowym i w odkrytym gruncie. Bioregulatory w stężeniach: 0, 100, 200, $400 \mathrm{mg} \mathrm{x} \mathrm{dm}^{-3}$ aplikowano dolistnie, dwukrotnie. Stwierdzono, że uprawa dzwonka brzoskwiniolistnego $\mathrm{w}$ nieogrzewanym tunelu foliowym przyspiesza kwitnienie roślin o około 2-3 tygodnie, w porównaniu z uprawą w odkrytym gruncie w pierwszym i drugim roku kwitnienia roślin. Celowe jest stosowanie kwasu giberelinowego w stężeniu 400 $\mathrm{mg} \mathrm{x} \mathrm{dm}{ }^{-3} \mathrm{w}$ uprawie dzwonka w tunelu foliowym i w stężeniu $200 \mathrm{mg} \mathrm{x} \mathrm{dm}^{-3} \mathrm{w}$ polu, gdyż zabieg ten przyspiesza kwitnienie o 2-9 days. Zaleca się stosowanie kwasu giberelinowego w stężeniu $400 \mathrm{mg} \mathrm{x} \mathrm{dm}^{-3}$, co wydłuża okres kwitnienia dzwonka brzoskwiniolistnego uprawianego w tunelu foliowym o 6-13 days. Uprawiając dzwonek brzoskwiniolistny w nieogrzewanym tunelu foliowym, można prognozować pełnię kwitnienia na pierwszy lub drugi tydzień od początku kwitnienia roślin. Uprawiając dzwonek w otwartym gruncie można spodziewać się wysypu kwiatostanów w drugim tygodniu kwitnienia roślin. Bez względu na rodzaj zastosowanej substancji w obu latach uprawy, w nieogrzewanym tunelu foliowym, najwięcej kwiatostanów nadawało się do cięcia w pierwszej dekadzie czerwca, a w polu w drugiej dekadzie czerwca. 